\title{
ANALISIS VARIASI NILAI TIME REPETITION (TR) DAN TIME INVERSION (TI) TERHADAP INFORMASI ANATOMI SEKUENS TURBO INVERSION RECOVERY MAGNITUDE (TIRM) MRI WRIST JOINT DENGAN MENGGUNAKAN MRI 0,3 TESLA
}

\section{ANALYSIS OF VARIATION OF TIME REPETITION (TR) AND TIME INVERSION (TI) VALUE TO ANATOMICAL INFORMATION USING TURBO INVERSION RECOVERY MAGNITUDE (TIRM) SEQUENCE WRIST JOINT MR IMAGING WITH 0,3 TESLA}

\author{
Slamet Fujiyanto $^{1)}$, Sugiyanto ${ }^{2)}$, M. Irwan Katili ${ }^{3)}$ \\ 1) Banyumas Regional General Hospital \\ ${ }^{2,3)}$ Health Polytechnics of Semarang-Indonesia \\ e-mail: ahmadrendraland@gmail.com
}

\begin{abstract}
Backgroud: The Turbo Inversion Recovery Magnitude (TIRM) pulse sequence is used to examine wrist joint, especially in the coronal plane. Main parameters of inversion recovery pulse sequence are time repetition (TR), time echo (TE) and time inversion (TI). This study aims to analyze the variation of time repetition (TR) and time inversion (TI) on anatomical information using TIRM pulse sequence on wrist joint MR imaging with 0,3 tesla.

Methods: This study was a quantitave experimental study with a linear regression test. This study was conducted in Radiology Department of Banyumas hospital using twenty serial images from only one patient with 10 variation of TR $(3000 \mathrm{~ms}, 3200 \mathrm{~ms}, 3400 \mathrm{~ms}, 3600 \mathrm{~ms}, 3800 \mathrm{~ms}$, $4000 \mathrm{~ms}, 4200 \mathrm{~ms}, 4400 \mathrm{~ms}, 4600 \mathrm{~ms}, 4800 \mathrm{~ms})$ and 10 variation of TI (70 ms, $75 \mathrm{~ms}, 80 \mathrm{~ms}, 85 \mathrm{~ms}, 90 \mathrm{~ms}, 95 \mathrm{~ms}, 100 \mathrm{~ms}, 105 \mathrm{~ms}, 110 \mathrm{~ms}$, $115 \mathrm{~ms})$. Image assessed by only one respondent.

Results: There was no significant influence of variation of TR and TI on anatomical information. Significant number was 0,240 which is bigger than $p$ value $(0,05)$. TR and TI variation affected just only $15,5 \%$ to anatomical information, $84,5 \%$ was influenced by other variables that unconfirmed in this study.

Conclusion: There was differences of anatomical information in MRI wrist joint sequence coronal T2WI-FSE fat suppression between SPIR and SPAIR with a significance level of $\mathrm{p}$ value $<0.001(\mathrm{p}<0.05)$. SPAIR is the method which is clearer to show the anatomical information of wrist joint.
\end{abstract}

Keywords : time repetition, time inversion, time inversion recovery magnitude, wrist joint MR imaging

\section{PENDAHULUAN}

Wrist joint adalah sendi bagian distal dari extremitas superior. Pada dasarnya sendi wrist mempunyai dua derajat kebebasan yaitu parmal-dorsal fleksi serta radial dan ulnar deviasi. Wrist joint disusun oleh tiga tulang yaitu tulang radius, tulang ulna dan tulang carpal. Tulang carpal terletak di pergelangan tangan yang kerangkanya di bentuk oleh delapan tulang carpal yang tersusun atas dua deretan. Deretan proximal terdiri naviculare, lunatum, triquertum, dan pisiformis. Deretan distal trapezium, trapezoideum, capitatum dan hamatum. Tulang-tulang carpal tangan susunannya membusur dengan bagian konkaf menghadap ke arah telapak tangan. Ruangan ini tertutup oleh ligamentum karpi transversum. Pemeriksaan wrist joint dapat dilakukan dengan pemeriksaan radiografi konvensional mapun CT scan, tetapi untuk menampakan citra musculosceletal yang lebih baik adalah dengan menggunakan pemeriksaan MRI.

Magnetic Resonance Imaging (MRI) adalah teknik pencitraan yang digunakan terutama dalam pemeriksaan medis untuk menghasilkan gambar berkualitas tinggi dari bagian dalam tubuh manusia. MRI didasarkan pada prinsipprinsip teknik resonansi magnetik (Hornak, 2011).

Pemeriksaan MRI pada Wrist Joint dilakukan untuk menilai kelainan pada triangular fibrocartilage complex (TFCC), scapolunate dan lunotriquetralligament, fraktur dari distal radius, scaphoid dan tulang karpal lainya yang terlihat normal pada radiograf, soft tissue injuries, kista ganglion, osteonecrosis tulang karpal dan lesi articular cartilage (Edmund, 2014)..

Dalam pencitraan MRI terdapat suatu istilah yang dikenal dengan pulsa sekuens. Pulsa Sekuens adalah serangkaian even yang meliputi pulsa radio frequency, pengaktifan gradient, dan pengumpulan sinyal yang dilakukan untuk menghasilkan gambaran MRI. Beberapa jenis sekuens yang sering digunakan dalam diagnostik klinis antara lain SekuensSpin Echo (SE), Fast Spin Echo (FSE), Gradient Echo (GRE), Inversion Recovery (IR), Echo Planar Imaging (EPI), serta Magnetic Resonance Angiography (MRA). Setiap sekuens memiliki parameter yang berbeda-beda untuk menghasilkan pembobotan yang berbeda-beda pula. Pembobotan kontras pada masing-masing sekuens tersebut memiliki karakteristik tertentu sehingga dapat digunakan untuk menilai suatu proses patologis (Bitar et al, 2006).

Inversion Recovery merupakan salah satu sekuens yang sering digunakan dalam diagnosa klinis. Pada Inversion Recovery pulsa $90^{\circ}$ diaplikasikan setelah pemberian pulsa $180^{\circ}$. Parameter utama pada Inversion Recovery adalah Time Repetition (TR), Time Echo (TE), dan Time Inversion (TI). Inversion Recovery terdiri dari Short Tau Inversion Recovery 
(STIR) dan Fluid Attenuated Inversion Recovery (FLAIR) (Bitar et al, 2006).

Gambaran STIR memiliki sinyal lemak yang sangat rendah namun sinyal cairan (fluid) sangat tinggi sehingga STIR disebut juga teknik imejing fatsuppressed pathology. Turbo Inversion Recovery Magnitude (TIRM) disebut juga dengan Turbo STIR. Aplikasi TIRM didapat dengan menggunakan parameter TI pendek dan TE panjang yang merupakan metode efektif dan stabil untuk fat supresi. TIRM digunakan untuk mendeteksi lesi dan mengevaluasi tumor. TIRM cocok untuk dokumentasi ukuran dan penyebaran tumor ke struktur anatomis (Diehl, 2000). Citra T2 weighted fat supresi atau STIR pada MRI wrist joint sangat sensitif untuk mendeteksi bone marrow edema (Edmund, 2014)

MRI wrist joint biasanya diperoleh di tiga penampang ortogonal yaitu potongan coronal, transversal dan sagital (Edmund, 2014). Menurut Moeller dan Reif (2003) pada MRI Wrist joint salah satu sekuens yang dibuat adalah STIR atau TIRM coronal. pada sekuens STIR atau TIRM Wrist joint digunakan untuk mengevaluasi wrist ligaments, triangular fibrocartilage complex (TFCC), dan articular cartilage (Edmund, 2014).

Optimisasi pada pemeriksaan MRI sangat perlu diketahui oleh seorang radiografer dengan cara mengetahui faktor apa saja yang mempengaruhi kualitas citra. Kualitas citra MRI yang optimal ditentukan oleh tiga karakteristik, yaitu contras to noise ratio (CNR), spatial resolusi, signal to noise ratio (SNR). CNR adalah perbedaan SNR antara organ yang saling berdekatan. CNR yang baik dapat menunjukan perbedaan daerah yang patologis dan sehat (Westbrook dan Kaut, 1998).

Pada Inversion Recovery, TR harus selalu dibuat cukup panjang untuk memungkinkan Net Magnetic Vector mengalami recovery penuh sebelum pulsa inversi berikutnya diaplikasikan. Untuk mendapatkan recovery penuh maka TR harus dibuat lebih dari $2000 \mathrm{~ms}$, namun konsekuensinya waktu scanning menjadi lama. Namun hal ini dapat diatasi dengan mengkombinasikan Inversion Recovery dengan Fast Spin Echo. TI adalah pengontrol kontras yang utama pada Inversion Recovery. TI medium akan menghasilkan T1WI, namun jika TI semakin diperpanjang maka akan menghasilkan gambaran Proton Density (Westbrook, 1999).

Menurut Brown (1998) nilai TI yang optimal berbeda-beda sesuai dengan kekuatan medan magnet. Untuk mengetahui nilai TI yang optimal pada suatu pesawat MRI maka perlu dilakukan suatu percobaan. Menurut Blink (2004) nilai TI yang optimal untuk pesawat 1,5 tesla adalah $160 \mathrm{~ms}$ dan untuk pesawat 0,3 tesla TI yang digunakan adalah $90 \mathrm{~ms}$.

Pemilihan nilai TI yang tidak tepat akan mempengaruhi tingkat fat supresi, selain itu TI juga berpengaruh pada CNR suatu citra yang akhirnya akan mempengaruhi kualitas citra MRI. Sedangkan pemilihan TR yang panjang akan meningkatkan SNR tetapi juga meningkatkan scan time sehingga resiko terjadinya motion artifact juga akan meningkat.

Tujuan dari penelitian ini adalah untuk mengetahui pengaruh variasi nilai Time Repetition (TR) dan Time inversion (TI) terhadap informasi anatomi sekuens Turbo
Inversion Recovery Magnitude (TIRM) MRI wrist Joint dengan menggunakan MRI 0,3 Tesla.

\section{METODE}

Jenis penelitian pada Karya Tulis Ilmiah ini adalah penelitian kuantitatif dengan pendekatan eksperimental yang bertujuan untuk mengetahui pengaruh variasi nilai Time Repetition (TR) dan Time inversion (TI) terhadap informasi anatomi sekuens Turbo Inversion Recovery Magnitude (TIRM) MRI wrist Joint dengan menggunakan MRI 0,3 Tesla.

Satu orang pasien pemeriksaan MRI wrist joint di Unit Radiologi Rumah Sakit Umum Daerah Banyumas sebagai sampel penelitian terkait. Responden yang memberikan penilaian terhadap citra MRI wrist joint sekuens TIRM adalah 1 (satu) orang dokter spesialis radiologi dengan pengalaman ekpertise MRI lebih dari 5 tahun.

Tabel 1. Kode Variasi TR

\begin{tabular}{ccc}
\hline kode serial & Variasi TR & Variasi TI \\
\hline A & $3000 \mathrm{~ms}$ & $90 \mathrm{~ms}$ \\
B & $3200 \mathrm{~ms}$ & $90 \mathrm{~ms}$ \\
C & $3400 \mathrm{~ms}$ & $90 \mathrm{~ms}$ \\
D & $3600 \mathrm{~ms}$ & $90 \mathrm{~ms}$ \\
E & $3800 \mathrm{~ms}$ & $90 \mathrm{~ms}$ \\
F & $4000 \mathrm{~ms}$ & $90 \mathrm{~ms}$ \\
G & $4200 \mathrm{~ms}$ & $90 \mathrm{~ms}$ \\
H & $4400 \mathrm{~ms}$ & $90 \mathrm{~ms}$ \\
I & $4600 \mathrm{~ms}$ & $90 \mathrm{~ms}$ \\
J & $4800 \mathrm{~ms}$ & $90 \mathrm{~ms}$ \\
\hline
\end{tabular}

Kemudian dilakukan scanning lagi dengan menggunakan variasi TI sedangkan variable lain tetap. Citra hasil penelitian dibuat tanpa keterangan apapun baik nama pasien maupun parameter yang digunakan, hanya diberi kode serial citra. Table 2. Kode Variasi TI

\begin{tabular}{ccc} 
kode serial & Variasi TI & Variasi TR \\
A & $70 \mathrm{~ms}$ & $3300 \mathrm{~ms}$ \\
B & $75 \mathrm{~ms}$ & $3300 \mathrm{~ms}$ \\
C & $80 \mathrm{~ms}$ & $3300 \mathrm{~ms}$ \\
D & $85 \mathrm{~ms}$ & $3300 \mathrm{~ms}$ \\
E & $90 \mathrm{~ms}$ & $3300 \mathrm{~ms}$ \\
F & $95 \mathrm{~ms}$ & $3300 \mathrm{~ms}$ \\
G & $100 \mathrm{~ms}$ & $3300 \mathrm{~ms}$ \\
H & $105 \mathrm{~ms}$ & $3300 \mathrm{~ms}$ \\
I & $110 \mathrm{~ms}$ & $3300 \mathrm{~ms}$ \\
J & $115 \mathrm{~ms}$ & $3300 \mathrm{~ms}$ \\
\hline
\end{tabular}

Prosedur dalam penelitian ini dimulai mengambil sampel 1 pasien wrist dengan klinis kelainan pada wrist joint, kemudian pasien diberi Inform Consent tentang maksud dan tujuan penelitian, penjelasan tentang prosedur dan jalannya pemeriksaan serta diyakinkan bahwa penelitian ini tidak berbahaya bagi pasien, jika sudah setuju dilakukan pembuatan citra MRI wrist joint, sekuens diawali dengan membuat 3 Plane Localiser untuk merencanakan potongan selanjutnya, dilakukan pembuatan citra MRI Wrist joint irisan Coronal dengan sekuens TIRM, posisi pasien Head first supine.Pasien discanning dengan 10 variasi TR, sedangkan parameter 
lainnya diatur tetap. Citra hasil penelitian dibuat tanpa keterangan apapun baik nama pasien maupun parameter yang digunakan, hanya diberi kode serial citra.

Seorang dokter spesialis radiologi dimohon untuk mencermati citra dari masing-masing gambar. Penilaian kualitatif berupa penilaian kejelasan informasi anatomi dari Triangular fibrocartilage complex (TFCC), Articular cartilage, Wrist ligament (soft tissue), Cairan, bone marrow.

Penilaian dokter spesialis radiologi dilakukan dengan memberikan tanda check $(\sqrt{ })$ pada kuisioner yang disediakan sesuai dengan petunjuk : Skor 1 untuk tidak jelas, Skor 2 untuk jelas, Skor 3 untuk sangat jelas.

Data dari hasil penilaian dokter spesialis radiologi berupa data ordinal akan dikonversi menjadi data interval dengan cara metods succesive interval. Setelah dilakukan metods succesive interval dengan aplikasi excel data yang diperoleh menjadi data interval yag kemudian akan dianalisis dengan metode regresi linier berganda.

Tujuan peneliti adalah mengetahui hubungan antara variasi TR dan TI terhadap informasi anatomi, oleh karena itu peneliti akan menggunakan analisis statistik regresi linier berganda karena memiliki dua variabel bebas dan satu variabel terikat. Fungsi dari regresi linier berganda adalah untuk mengetahui hubungan kedua variabel bebas baik positif atau negatif, dan akan menghasilkan persamaan linier untuk memprediksi pengaruh 2 variabel bebas tadi terhadap variabel terikatnya.

\section{HASIL}

Penelitian ini dilakukan dengan 10 variasi nilai Time Repetition (TR) dan 10 variasi nilai Time Inversion (TI) pada sekuens Turbo Inversion Recovery Magnitude (TIRM) pada MRI wrist joint potongan Coronal. Variasi nilai TR yang digunakan pada penelitian ini dari nilai $3000 \mathrm{~ms}, 3200 \mathrm{~ms}$, $3400 \mathrm{~ms}, 3600 \mathrm{~ms}, 3800 \mathrm{~ms}, 4000 \mathrm{~ms}, 4200 \mathrm{~ms}, 4400 \mathrm{~ms}$, $4600 \mathrm{~ms}$ dan $4800 \mathrm{~ms}$ dengan nilai TI diatur tetap $90 \mathrm{~ms}$ kemudian digunakan variasi nilai TI dari $70 \mathrm{~ms}, 75 \mathrm{~ms}, 80 \mathrm{~ms}$, $85 \mathrm{~ms}, 90 \mathrm{~ms}, 95 \mathrm{~ms}, 100 \mathrm{~ms}, 105 \mathrm{~ms}, 110 \mathrm{~ms}, 115 \mathrm{~ms}$ dengan TR diatur tetap $3300 \mathrm{~ms}$
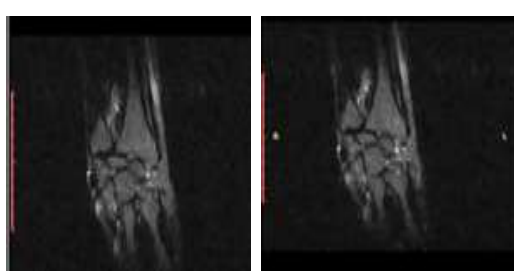

TR 3000 TI 90

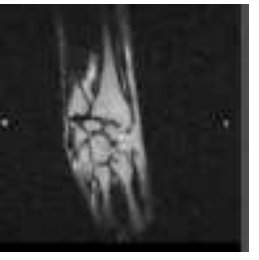

TR 3800 TI 90

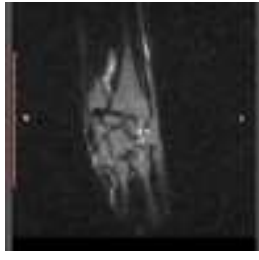

TR 3300 TI 95

TR 3300 TI 70

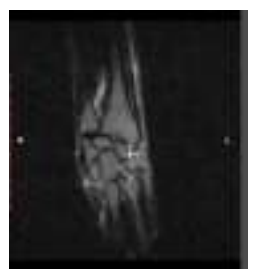

TR 4800 TI 90

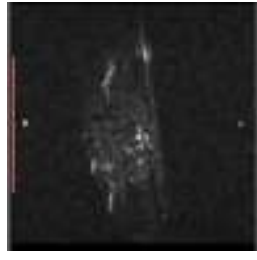

TR3300 TI 115

Gambar 1. MRI wrist joint potongan Coronal

Penelitian ini sampel diambil secara acak pada pemeriksaan wrist joint potongan coronal sekuens TIRM sebanyak 1 orang. Setelah dilakukan MRI wrist potongan coronal sekuens TIRM citra yang dihasilkan dicetak pada film ukuran 14x17 cm tanpa memberikan identitas dengan hanya memberikan kode pada setiap serial variasi dengan huruf $A$ sampai T. Citra MRI wrist joint potongan coronal yang didapatkan.

Dari 20 variasi TR dan TI yang dilakukan dihasilkan 20 serial citra yang menampakan citra anatomi Triangular fibrocartilage complex (TFCC), articular cartilage, wrist ligament, cairan dan bone marrow. Kemudian seorang dokter spesialis radiologi sebagai responden dimohon untuk menilai kejelasan informasi anatomi yang dihasilkan.

pengaruh variasi nilai Time Repetition terhadap informasi anatomi dengan nilai Time Inversion diatur tetap (90 ms)

Tabel 3. Pengaruh variasi nilai Time Repetition terhadap nilai informasi anatomi dengan nilai Time Inversion diatur tetap (90 ms)

\begin{tabular}{llllll}
\hline Variabel & \multicolumn{5}{c}{ Informasi Anatomi } \\
\cline { 2 - 6 } TR 3000 & 1 & 1 & 1 & 2 & 2 \\
TR 3200 & 1 & 1 & 1 & 2 & 2 \\
TR 3400 & 1 & 1 & 1 & 3 & 2 \\
TR 3600 & 2 & 1 & 1 & 2 & 2 \\
TR 3800 & 1 & 2 & 2 & 2 & 2 \\
TR 4000 & 1 & 1 & 2 & 2 & 2 \\
TR 4200 & 1 & 1 & 2 & 2 & 2 \\
TR 4400 & 2 & 1 & 2 & 2 & 2 \\
TR 4600 & 1 & 2 & 2 & 2 & 2 \\
TR 4800 & 1 & 2 & 2 & 2 & 2 \\
\hline
\end{tabular}

Berdasarkan tabel 3 dapat dideskripsikan bahwa pada nilai TR $3600 \mathrm{~ms}$ dan $4400 \mathrm{~ms}$ mampu menampakan Triangular fibrocartilage complex (TFCC) dengan jelas sedangkan pada nilai TR yang lain tampak tidak jelas.Pada nilai TR $3800 \mathrm{~ms}$, $4600 \mathrm{~ms}$, dan $4800 \mathrm{~ms}$ mampu menampakan articular cartilage dengan jelas sedangkan pada nilai TR yang lain tidak jelas. Pada nilai TR 3800 ms, 4000 ms, 4200 ms, 4400 $\mathrm{ms}, 4600 \mathrm{~ms}$, dan 4800 mampu menampakan wrist ligament dengan jelas dan pada nilai TR yang lain tidak jelas. Pada nilai TR 3400 ms mampu menampakan cairan/fluid dengan sangat jelas sedangkan pada nilai TR yang lain mampu menampakan nilai TR dengan jelas.Semua variasi nilai TR pada penelitian ini mampu menampakan bone marrow dengan jelas.

Berdasarkan table 4 dapat dideskripsikan bahwa pada nilai TI $80 \mathrm{~ms}, 85 \mathrm{~ms}$, dan $95 \mathrm{~ms}$ mampu menampakan Triangular fibrocartilage complex (TFCC) dengan sangat jelas, nilai TI 90 mampu menampakan TFCC dengan jelas sedangkan pada nilai TI yang lain tampak tidak jelas. Pada nilai TI $95 \mathrm{~ms}$ mampu menampakan articular cartilage dengan sangat jelas, nilai TI $70 \mathrm{~ms}, 75 \mathrm{~ms}, 80 \mathrm{~ms}, 85 \mathrm{~ms}, 90 \mathrm{~ms}$ dan $100 \mathrm{~ms}$ mampu menampakan articular cartilage dengan jelas sedangkan pada nilai TI yang lain tidak jelas.Pada nilai TI 85 $\mathrm{ms}, 95 \mathrm{~ms}$, dan $100 \mathrm{msmampu}$ menampakan wrist ligament dengan sangat jelas, nilai TI $70 \mathrm{~ms}, 75 \mathrm{~ms}, 80 \mathrm{~ms}, 90 \mathrm{~ms}$ dan 
$105 \mathrm{~ms}$ mampu menampakan wrist ligament dengan jelas sedangkan nilai TI $110 \mathrm{~ms}$ dan 115 tidak jelas

Pengaruh variasi nilai Time Inversion terhadap informasi anatomi dengan nilai Time Repetition diatur tetap (3300 ms)

Tabel 4. Pengaruh variasi nilai Time Inversion terhadap nilai informasi anatomi dengan nilai Time Repetition diatur tetap (3300 ms)

\begin{tabular}{llllll}
\hline Variabel & \multicolumn{5}{c}{ Informasi Anatomi } \\
\cline { 2 - 6 } TI 70 & TFCC & AC & WL & F & BM \\
TI 75 & 1 & 2 & 2 & 2 & 2 \\
TI 80 & 3 & 2 & 2 & 2 & 2 \\
TI 85 & 3 & 2 & 2 & 2 & 2 \\
TI 90 & 2 & 2 & 2 & 3 & 2 \\
TI 95 & 3 & 3 & 3 & 3 & 3 \\
TI 100 & 1 & 2 & 3 & 3 & 3 \\
TI 105 & 1 & 1 & 2 & 2 & 1 \\
TI 110 & 1 & 1 & 1 & 1 & 1 \\
TI 115 & 1 & 1 & 1 & 1 & 1 \\
\hline
\end{tabular}

Pada nilai 95 ms, 95 ms, dan 100 ms mampu menampakan cairan/fluid dengan sangat jelas, nilai TI $70 \mathrm{~ms}, 75 \mathrm{~ms}, 80 \mathrm{~ms}$, dan $85 \mathrm{~ms}$ mampu menampakan cairan/fluid dengan jelas sedangkan pada nilai TI $110 \mathrm{~ms}$ dan $115 \mathrm{~ms}$ tidak jelas.

Pada nilai TI $95 \mathrm{~ms}$ dan $100 \mathrm{~ms}$ mampu menampakan bone marrow dengan sangat jelas, nilai TI $70 \mathrm{~ms}, 75 \mathrm{~ms}, 80$ $\mathrm{ms}, 85 \mathrm{~ms}, 90 \mathrm{~ms}$ mampu menampakan bone marrow dengan jelas sedangkan pada nilai TI $110 \mathrm{~ms}$ dan $115 \mathrm{~ms}$ tidak jelas.

Hasil uji statistik pengaruh variasi TR dan TI terhadap informasi anatomi sekuens turbo inversion Recovery magnitude (TIRM) MRI Wrist Joint dengan menggunakan MRI 0,3 Tesla. Untuk menilai pengaruh variasi TR dan TI terhadap informasi anatomi sekuens turbo inversion Recovery magnitude (TIRM) MRI Wrist Joint dengan menggunakan MRI 0,3 Tesla metode analisis yang dipakai adalah regresi linier berganda karena menggunakan dua variabel bebas.

Sebelum dilakukan uji regresi linier berganda dilakukan uji normalitas pada residual data penelitian, dengan tujuan untuk menilai baik atau tidaknya model regresi yang akan digunakan. Pada penelitian ini nilai $P$ value 0,351 atau $p$ value $>0,05$ maka nilai residual data penelitian normal artinya model regresi yang digunakan baik.

Dari tabel 5 diperoleh $\mathrm{F}$ hitung sebesar 1,554. kemudian untuk menguii hipotesa harus diketahui nilai $\mathrm{F}$ tabel. Sedangkan $\mathrm{F}$ tabel didapatkan dengan cara menentukan nilai df1 dan df2 yaitu dengan rumus:

Tabel 5. Pengaruh Variasi Nilai TR dan TI Terhadap Informasi Anatomi sekuens Turbo Inversion Recovery Magnetude (TIRM) MRI wrist Joint menggunakan MRI 0,3 Tesla

\begin{tabular}{llll}
\hline Variabel & F & R Square & Sig \\
\hline TR dan TI & 1,554 & .155 & .240 \\
Informasi Anatomi & & & \\
\hline
\end{tabular}

df1 $=\mathrm{K}-1$

$\mathrm{df} 2=(\mathrm{n}-\mathrm{k}-1)$

Keterangan :

$\mathrm{K}$ : jumlah variabel

$\mathrm{n}$ : jumlah kasus atau variasi

$\mathrm{k}$ : jumlah variabel bebas

Pada penelitian ini menggunakan dua variabel bebas dan 20 variasi maka dari rumus diatas nilai df1 diperoleh 2 dan df2 diperoleh 17. Seteah nilai df1 dan df2 diperoleh maka akan diketahui nilai $\mathrm{F}$ tabel probabilita 0,05 dengan melihat tabel titik presentasi distribusi $\mathrm{F}$ (lihat lampiran) untuk probabilita 0,05 dimana df1 sebagai pembilang dan df2 sebagai penyebut atau dengan ms Excell dengan cara pada cell kosong diketik $=$ finv $(0.05,2,17)$ maka diperoleh $F$ tabel sebesar 3,59. Dari hasil uji F maka dapat diketahui bahwa $\mathrm{F}$ hitung < $\mathrm{F}$ tabel maka $\mathrm{H}_{0}$ dinyatakan diterima atau tidak ada pengaruh yang sigifikan dari TR dan TI terhadap informasi anatomi wrist joint. Hal ini juga dapat dilihat pada tabel $4.3 p$ value sebesar 0,240 ( $p>0,05)$.

Untuk mengetahui prosentase sumbangan pengaruh TR dan TI terhadap informasi anatomi, dilakukan analisis determinasidengan melihat nilai $\mathrm{R}$ square. Dari tabel 4.3 diketahui nilai $\mathrm{R}$ square 0,155 atau $15,5 \%$, yang berarti prosentase sumbangan pengaruh TR dan TI terhadap informasi anatomi adalah sebesar 15,5 \%, sedangkan sisanya $(84,5 \%)$ dipengaruhi oleh variabel lain yang tidak dimasukan dalam penelitian ini.

Pada uji regresi linier berganda akan didapatkan persamaan regresi dengan melihat tabel coefficients.

Tabel 6. koefisien Regresi

\begin{tabular}{cc} 
& \multicolumn{2}{c}{ B } \\
(Constant) & 23,584 \\
Nilai TR & $10^{-6}$ \\
Nilai TI &,- 120 \\
\hline
\end{tabular}

Dari tabel 6 persamaan regresi yang didapat adalah:

$$
\begin{aligned}
& Y^{\prime}=a+b 1 X 1+b 2 X 2 \\
& Y^{\prime}=23,584+10^{-6} \mathrm{X} 1+(-0,120) X 2 \\
& Y^{\prime}=23,584+10^{-6} \mathrm{X} 1-0,120 \mathrm{X} 2 \ldots \ldots
\end{aligned}
$$

$$
\begin{aligned}
& \text { Keterangan : } \\
& \mathrm{Y}^{\prime}=\text { Informasi Anatomi yang diprediksi } \\
& \mathrm{a}=\text { konstanta } \\
& \mathrm{b} 1, \mathrm{~b} 2=\text { koefisien regresi } \\
& \mathrm{X} 1=\mathrm{TR} \\
& \mathrm{X} 2=\mathrm{TI}
\end{aligned}
$$

Dari persamaan regresi 2 bermakna koefisien regresi variabel TR $1 \times 10^{-6}$ atau bernilai positifartinya jika variabel yang lain (TI) tetap dan TR mengalami kenaikan $200 \mathrm{~ms}$ maka informasi anatomi akan mengalami kenaikan sebesar $2 \times 10^{-4}$.

Koefisien regresi variabel TI $-0,12$ atau bernilai negatifartinya jika variabel yang lain (TR) tetap dan TI mengalami kenaikan $5 \mathrm{~ms}$ maka informasi anatomi akan mengalami penurunan sebesar 0,6.

Kemudian dilakukan pengujian pengaruh variasi nilai Time Repetition (TR) dan Time Inversion (TI) terhadap 
masing kriteria informasi anatomi dan didapatkan hasil sebagai

Tabel 7 Pengaruh TR dan TI terhadap masing-masing Kriteria Informasi Anatomi

\begin{tabular}{ll}
\hline Kriteria Informasi Anatomi & Sig \\
\hline TFCC & 0.461 \\
AC & 0,267 \\
WL & 0.575 \\
F & 0.395 \\
BM & 0.160 \\
\hline
\end{tabular}

Dari tabel 7 dapat diketahui bahwa p-value dari masingmasing kriteria anatomi wrist joint sekuens TIRM MRI Wrist joint dengan menggunakan MRI 0,3 $\mathrm{T}$ adalah > 0.05 yang artinya tidak ada pengaruh yang signifikan dari variasi nilai TR dan TI terhadap masing-masing kriteria anatomi wrist joint.

\section{DISKUSI}

Dari hasil penelitian ini diketahui bahwa tidak ada pengaruh variasi nilai time repetition (TR) dan time inversion (TI) terhadap informasi anatomi sekuens Turbo Inversion Recovery Magnitude (TIRM) MRI Wrist Joint dengan menggunakan MRI 0,3 T $(p>0,05)$ atau Ho diterima. Hasil penelitian ini juga menyebutkan bahwa sumbangan pengaruh TR dan TI terhadap informasi anatomi sekuens TIRM MRI wrist joint dengan menggunakan 0,3 tesla sangat kecil sekali yaitu hanya 15,5\% dan sisanya sebesar 84,5\% kemungkinan dipengaruhi oleh variabel lain yang tidak dimasukan dalam penelitian ini.

Menurut Westbrook dan Kaut, 2011 bahwa kualitas gambar MRI yang optimal dtentukan oleh 4 karakteristik, yaitu contrast to noise ratio (CNR), spatial resolusi, signal to noise ratio (SNR) dan scan time. Signal to noise ratio adalah perbandingan antara besarnya amplitudo sinyal dengan noise amplitude. SNR dipengaruhi oleh kekuatan medan magnet yang digunakan densitas Proton daerah yang diperiksa, field of view, Tebal Irisan/slice thickness, slice gap, Echo train lenght ,Time Echo, Number of Exitation, Receive Bandwidth, Penggunaan koil yang dipasang sedekat mungkin dengan obyek. CNR adalah perbedaan SNR yang saling berdekatan. Spatial resolution adalah kemampuan untuk membedakan anatra dua titik secara terpisah dan jelas. Spatial resolution dipengaruhi oleh slice thickness, matriks, dan FOV.

Menurut penulis kecilnya nilai sumbangan pengaruh TR dan TI terhadap informasi anatomi $(15,5 \%)$ dikarenakan TR dan TI hanya mempengaruhi kualitas citra yang secara tidak langsung akan mempengaruhi informasi anatomi. Sedangkan kualitas citra dipengaruhi banyak faktor diantaranya kekuatan medan magnet yang digunakan, proton daerah yang diperiksa, FOV, slice thickness, slice gap, ETL, TE, NEX, Receive Bandwidth, koil receiver dan matriks.

Dari uji regresi linier berganda didapatkan persamaan linier $Y^{\prime}=23,584+10^{-6} \mathrm{X} 1-1,20 \mathrm{X} 2$ dimana $\mathrm{Y}$ adalah nilai informasi anatomi, $\mathrm{X} 1$ adalah nilai TR dan $\mathrm{X} 2$ adalah nilai TI. Dari persamaan linier ini dapat diartikan bahwa nilai TR berpengaruh positif terhadap informasi anatomi dan nilai TI berpengaruh negatif terhadap informasi anatomi.

Pemeriksaan MRI Wrist dengan sekuens STIR atau TIRM digunakan untuk mengevaluasi wrist ligament, TFCC dan articular cartilage. STIR juga sangat sensitif dalam mendeteksi bone marrow edema (Edmud, 2014). Nilai TR pada penelitian ini berpengaruh positif terhadap nilai informasi anatomi. Hal ini sesuai menurut Wesbrook dan Kaut (2011) pada Inversion Recovery, TR harus selalu dibuat cukup panjang untuk memungkinkan NMV mengalami recovery penuh sebelum pulsa inversi berikutnya diaplikasikan. Untuk mendapatkan recovery penuh maka TR harus dibuat lebih dari 2000 ms. TR mengontrol jumlah magnetisasi longitudinal yang mengalami recovery sebelum eksitasi pulsa berikutnya diterapkan, TR yang panjang memungkinkan recovery penuh dari magnetisasi longitudinal sehingga TR yang meningkat akan meningkatkan SNR.

Tetapi pada penelitian ini TR memiliki pengaruh yang sangat kecil yaitu sebesar $10^{-6}$. Hal ini disebabkanpada penelitian ini menggunakan modalitas MRI dengan kuat magnet (Bo) yang rendah yaitu 0,3 Tesla.Nilai Bo mempengaruhi Net Magnetisation Vector (NMV) yang terbentuk. Dengan Bo yang rendah, maka hanya sebagian kecil proton hidrogen yang akan berada pada lower state energy (parallel terhadap Bo) sehingga nilai NMV yang dihasilkan sangat rendah. NMV akan berpengaruh pada besar sinyal yang dihasilkan, dimana rendahnya nilai NMV, maka sinyal yang diterima receiver akan menjadi rendah. Peningkatan nilai TR tidak akan berpengaruh signifikan terhadap informasi citra yang dihasilkan ketika NMV yang digunakan dalam pencitraan memiliki nilai yang sangat rendah. Hal ini sesuai menurut Westbrook dan Kaut, 2011 bahwakekuatan medan magnet berperan penting dalam menentukan SNR, NMV akan meningkat pada penggunaan medan magnet yang tinggi sehingga akan lebih banyak magnetisasi yang digunakan pada pencitraan pasien. Edmund Lee pada ACR Journal juga menyebutkan bahwa untuk pencitraan MRI Wrist joint dengan resolusi yang tinggi didapatkan dengan menggunakan medan magnet dengan Bo tinggi $(\geq 1.0 \mathrm{~T})$.

Nilai TI berpengaruh negatif terhadap informasi anatomi diakibatkan oleh karakteristik TI yang diaplikasikan pada sekuens TIRM. Penggunaan nilai TI yang tinggi akan menghasilkan fat suppression yang berlebihan.Hal ini dikarenakan sekuen TIRM berpengaruh terhadap jaringan sekitar yang mempunyai waktu relaksasi sama seperi lemak, sehingga organ yang mempunyai nilai TI yang sama dengan lemakakan ikut tersupresi dan menghasilkan gambaran yang gelap pada citra.Hal ini sesuai menurut Price dan Graves (2006), dengan mengatur nilai TI yang tepat maka dapat dihasilkan kontras yang baik antara air dan lemak karena adanya saturasi penuh dari vektor air dan lemak. Tidak hanya lemak, STIR juga akan mensupresi atau menekan jaringan yang mempunyai T1 (waktu relaksasi) yang sama dengan lemak.Selain itu sekuens TIRM menerapkan teknik supresi non selective dimana seluruh NMV akan terinversi sesuai dengan flip angle yang digunakan sehingga ketika pulsa 
eksitasi diterapkan NMV organ selain lemak belum mengalami recovery optimal yang menyebabkan sinyal yang ditangkap receiver menjadi rendah.

Persamaan linier ini juga dapat dijadikan prediksi nilai informasi anatomi yang dihasilkan, apabila nilai TI tetap dan TR mengalami kenaikan 200ms maka informasi anatomi akan mengalami kenaikan $2 \times 10^{-4}$. Dan apabila nilai TR tetap dan TI mengalami kenaikan $5 \mathrm{~ms}$ maka informasi anatomi akan mengalami penurunan 0,6 .

\section{SIMPULAN}

Tidak ada pengaruh variasi nilai Time repetition dan time inversion terhadap informasi anatomi pada sekuens Turbo Inversion Recovery (TIRM) MRI wrist joint dengan menggunakan MRI 0,3 Tesla dengan nilai significant 0,240 lebih besar dari $p$ value $(0,05)$.

Sumbangan pengaruh variasi nilai TR dan TI terhadap informasi anatomi hanya sebesar $15,5 \%$ dan sisanya sebesar $84,5 \%$ dipengaruhi oleh variabel lain yang tidak dimasukan dalam penelitian ini.

\section{DAFTAR PUSTAKA}

Bitar, Richard, et al. 2006. MR Pulse Sequences: What Every Radiologist Wants to Know but Is Afraid to As, RSNA Volume 26,

Evert, J. 2004. MRI:Physics, http://www Number 2. Diakses tanggal 15 Februari 2016

Brown, Greg. 1998. Fat Suppression Techniques, www.users.on.net.htm. Diakses tanggal 10 Maret 2016.

Bryan, S. Wetherburn, G. Bungay, H. Hatrick, C. Salas, C. Parry, D. Field, S. Heatly, F. 2001. The costeffectiveness of magnetic resonance imaging for investigation of the knee joint. HealthTechnol Assess ; 5.

Diehl, JS. Sadiek, M. Gaa, J. Mockel, R. Bergiler, W. Georgi, M. 2000. Turbo Inversion Recovery Imaging in the Diagnosis of Head and Neck Tumors. www.cds.ismrm.org/ismrm-1999/PDF4/980.pdf Diakses tanggal 10 maret 2016.

Edmund, J.H. 2014. ACR-SCBT-MR-SPR-SSR Practice Parameter for The Performance Of Magnetic Resonance Imaging (MRI) of The Wrist

Hornak, JP. 2011. The Basic of MRI. www.cis.rit.edu Di akses tanggal 10 Maret 2016.

Kuperman, Vadim. 2000. MRI Physical Priciples and Applications. USA: Academic Press.

Moeller dan Reif. 2003. MRI Parameters and Positioning. New York : Thieme.

Ness, Aiver. 1996. All you really need to know About MRI Physics. University of Maryland Medical Center, USA.

Radiol, Pediatr. 2008. Comparison of turbo inversion recovery magnitude (TIRM) with T2-weighted turbo spin-echo and T1-weighted spinecho MR imaging in the early diagnosis of acute osteomyelitis in children. US National Library Medicine Institute of Health.

Westbrook, Catherine. 1999. Handbook of MRI Technique, Second Edition. London: Blackwell Science.

Westbrook dan Kaut. 1998. MRI In Practise, Second Edition. London: Blackwell Science

Westbrook dan Kaut. 2011. MRI In Practise, third edition. London: Blackwell Science

Wishput, D. Kochli, VD, Marincek, B. 2006. How MRI Work?. Germany : Springer.

Woodburne, Russel T. 1983. Essential Off Human Anatomy.seventh edition. New York: oxford university Press 